\title{
Impact of Phosphorous and Zinc Levels on the Productivity of Green Gram (Vigna radiate L.)
}

Aman Khan ( $\nabla$ amanuaf@gmail.com )

The University of Agriculture Peshawar, Amir Muhammad Khan Campus Mardan

\section{Research Article}

Keywords: Alpha lattice design, genotypes, sowing time, wheat yield and yield components

Posted Date: January 25th, 2022

DOI: https://doi.org/10.21203/rs.3.rs-1288485/v1

License: (c) (i) This work is licensed under a Creative Commons Attribution 4.0 International License. Read Full License 


\section{Abstract}

Mung bean is one of the important Kharif pulses in Pakistan and is grown mainly for its edible seeds; therefore, fertilizers management is an important factor for improving mungbean growth and yield. A field experiment was conducted during the summer of 2013 at Palato Farm of the University of Agriculture Peshawar, Amir Muhammad Khan Campus Mardan, to determine the effect of phosphorus $(P)$ and Zinc $(\mathrm{Zn})$ on the yield and yield component of mungbean. The experiment consisted of four levels of $P(0,25$, 50 , and $\left.75 \mathrm{~kg} \mathrm{ha}^{-1}\right)$ and four levels of $\mathrm{Zn}\left(0,5,10\right.$, and $\left.15 \mathrm{~kg} \mathrm{ha}^{-1}\right)$. Data associated with the number of leaves and plant height illustrated that the higher number of leaves plant ${ }^{-1}(8.8)$ by an average was observed when $P$ was applied at the rate of $75 \mathrm{~kg} \mathrm{ha}^{-1}$ followed by $0 \mathrm{~kg}$ phosphorous $(P) \mathrm{ha}^{-1}(8.7)$ and $\mathrm{Zn}(\mathrm{Zn})$ application at the rate of $10 \mathrm{~kg} \mathrm{ha}^{-1}$ produced a maximum number of leaves plant ${ }^{-1}$ (9) followed by $15 \mathrm{~kg} \mathrm{ha}^{-1}$ (8.8) where $0 \mathrm{~kg} \mathrm{ZN} \mathrm{ha}^{-1}$ resulted in (7.7). Similarly, Zn significantly affected plant height, while $P$ and interaction between $P$ and $Z n$ levels were non-significant. The higher plant height $(95.1 \mathrm{~cm})$ was observed when $P$ was applied at the rate of $75 \mathrm{~kg} \mathrm{ha}^{-1}$, followed by $50 \mathrm{~kg} \mathrm{P} \mathrm{ha}^{-1}(93.6 \mathrm{~cm})$. Higher plant height $(95.8 \mathrm{~cm})$ was recorded when ZN was applied at the $5 \mathrm{~kg} \mathrm{ha}^{-1}$ followed by $10 \mathrm{~kg}$ $\mathrm{ha}^{-1}(95.1 \mathrm{~cm})$. Higher numbers of nodules (13.1) were observed with the application of $50 \mathrm{~kg} \mathrm{Pha}^{-1}$ followed by $75 \mathrm{~kg} \mathrm{P} \mathrm{ha}^{-1}$ (12.3), while the lowest (10.6) nodules were observed in the control plot. $\mathrm{P}$ application at the rate of $25 \mathrm{~kg} \mathrm{ha}^{-1}$ produced a higher grain yield than 75 and $50 \mathrm{~kg}$ ha-1 and $\mathrm{Zn}$ application at the rate of $5 \mathrm{~kg}$ ha-1 produced a higher grain yield than 10 and $15 \mathrm{~kg} \mathrm{ha}^{-1}$. Therefore, a lower rate of $\mathrm{P} 25 \mathrm{~kg} \mathrm{ha}^{-1}$ and $\mathrm{Zn} 5 \mathrm{~kg} \mathrm{ha}^{-1}$ is recommended for a higher yield of mungbean in the agroecological condition of Mardan.

\section{Introduction}

Mungbean (Vigna radiate L.), also called green gram, is an important summer-growing pulse crop in Pakistan (Hakim et al., 2021; Ali et al., 2019; Ahmad et al., 2003). It contains $24.5 \%$ protein and $59.9 \%$ carbohydrates. It also contains $75 \mathrm{mg}$ calcium, $8.5 \mathrm{mg}$ iron, and $49 \mathrm{mg} \beta$-carotene per $100 \mathrm{~g}$ of split dal (Hakim et al., 2021; Shakya et al., 2019). The foliage and stem are good sources of fodder for livestock. Its seed is more palatable nutritive, digestible, and non-flatulent than other pulses (Teferie et al., 2020; Tarafder et al., 2020). The unique and common feature of mungbean is the root nodules that contain aerobic bacteria called rhizobia which fix atmospheric nitrogen in the root and thus enhance soil fertility (Singh et al, 2021; Ashraf et al., 2003). It is also a substitute for animal protein and forms a balanced diet when used with cereals (Detzel et al., 2021). In Pakistan, mungbean is cultivated as a minor crop and used as food. The area under mungbean in Pakistan was around 141 thousand hectares, with 93 thousand tons in 2011 (Hakim et al., 2021; GOP, 2012).

Fertilizers management is one of the important factors for improving the growth and yield of mung-bean (Ali et al., 2019; Iqbal et al., 2021; Ullah et al., 2020). Phosphorous is an essential component of ADP, ATP, the cell wall, and DNA and plays a key role in promoting plants storage and structural activities (Aimen et al., 2021). $P$ is an important element that significantly affects plant growth and metabolism (Amanullah 
et al., 2022; Sadiq et al., 2017; Bashir et al., 2011) and is a component of DNA and RNA, involved in cell division (Brady and Weil, 2004). Nodule establishment and its function are important sinks for $P$, and nodules usually have the highest $P$ content in the plant (Sulieman et al., 2015). It is supposed that $P$ is effectively translocated into grain at high rates since $P$ is necessary for producing protein, phospholipids and phytin in bean grain (Rahman et al., 2008). Poor nodulation and poor plant vigour are observed in beans grown in $\mathrm{P}$ deficient soils (Bindraban et al., 2020). Among other essential factors, an appropriate supply of micronutrients is also required for crops' proper growth and yield. The importance of $\mathrm{Zn}$ as a micronutrient in crop production has increased in recent years (Amanullah et al., 2020; Thapa et al., 2021). Hence $Z n$ is considered the most yield-limiting micronutrient (Arunachalam et al., 2013).

The $\mathrm{Zn}$ application essentially is being employed in the functional and structural components of several enzymes (Amanullah et al., 2020; Read et al., 2019), such as carbonic anhydrase, alcohol dehydrase, alkaline phosphatase, phospholipase, carboxypeptidase (Read et al., 2019) and RNA polymerase (Romheld and Marschner., 1991). Furthermore, plants that emerged from seeds with lower Zn could be susceptible to biotic and abiotic stresses (Rehman et al., 2018). Zn enriched seeds perform better concerning seed germination, seedling growth, and yield of crops (Haider et al., 2020). In addition, Zn acts as an activator of several enzymes in plants and is directly involved in the biosynthesis of growth substances such as auxin, which produces more plant cells (Umair et al., 2020; Gobarah et al., 2006). Furthermore, $\mathrm{Zn}$ enhanced photosynthesis at the early growth of plants, improved nitrogen fixation, grain protein, and yields of mungbean plants (Umair et al., 2020). In Pakistan, Zn scarcity in the soil is the first most widespread problem. In Khyber Pukhtunkhwa, the extent of Zn deficient soils ranges from $21 \%$ to $77 \%$. $42 \%$ of agricultural fields of Mansehra and Swat have a Zn deficiency. On average, $37 \%$ of fields are deficient in Zn (Ahsin et al., 2020).

Therefore, the present experiment was designed to study the effect of different levels of $P$ and $Z n$ on the yield of mungbean and find out the best combinations of $\mathrm{P}$ and $\mathrm{Zn}$ for higher yield and yield components of mungbean under the agro-climatic condition of Mardan.

\section{Materials And Methods}

\subsection{Experimental design}

A field experiment was conducted during the summer of 2013 at Palato Farm of the University of Agriculture Peshawar, Amir Muhammad Khan Campus Mardan (Figure 1), to determine the effect of $P$ and $\mathrm{Zn}$ on the yield and yield component of mungbean. The experiment was conducted in a randomized complete block design with three replications, and the plot size was $2 \mathrm{~m} \times 1.8 \mathrm{~m}$. Mungbean variety "Ramzan" was sown in lines having five rows $35 \mathrm{~cm}$ apart on July 2, 2013. The experiment consisted of four levels of $P\left(0,25,50\right.$ and $\left.75 \mathrm{~kg} \mathrm{ha}^{-1}\right)$ and four levels of $Z n\left(0,5,10\right.$, and $\left.15 \mathrm{~kg} \mathrm{ha}^{-1}\right)$. SSP and $\mathrm{ZnSO}_{4}$ will be used as the source of $\mathrm{P}$ and $\mathrm{Zn}$, respectively and applied as a whole during seedbed preparation. All other agronomic practices, such as weeding, irrigation, plant protection measures, etc., were normal and uniform for all the experimental units. 


\subsection{Data collection and measurement}

The number of plants $\mathrm{m}^{-2}$ were recorded from three central rows by counting the number of plants within the metering rod of each row and was converted to $\mathrm{m}^{-2}$. Data on the number of branches plant $^{-1}$ was recorded by selecting five plants randomly from each treatment, and the number of branches were counted from base to top and were averaged. The number of leaves plant ${ }^{-1}$ was recorded by selecting five plants randomly from each treatment, and the number of leaves was counted from base to top and averaged. Data on plant height was recorded by randomly selecting five plants from each treatment and measuring its height from base to tip and then averaged to record plant height and averaged them. The number of pod plant ${ }^{-1}$ was recorded by selecting five plants randomly from each plot and then were picked from it, and the number of pods was counted, and then the mean was calculated. Data on the number of grain pod $^{-1}$ was recorded by counting the number of grains from five randomly selected pods in each plot and then averaged. Numbers of nodules plant- 1 were recorded by selecting three plants randomly from each treatment, and the number of nodules were counted on roots and averaged. Data on Biological yield $\left(\mathrm{kg} \mathrm{ha}^{-1}\right)$ was recorded by harvesting three central rows in each plot and kept in the field for sun drying. It was weighed with the help of scale and converted into $\mathrm{kg} \mathrm{ha}^{-1}$ by this formula.

(Weight of bundles/ No. of rows, *Row length * row to row distance) $\times 10000$

Data on grain yield was recorded by harvesting one square meter area from each plot and then were threshed, cleaned, dried, and weighed. The dried grains were weighed with the help of electronic balance and then converted to $\mathrm{kg} \mathrm{ha}^{-1}$. Data on thousand grains weight $(\mathrm{g})$ was recorded by counting 1000 grains from each plot and then were weighed with the help of a sensitive electrical balance. The harvest index was calculated using the formula.

Harvest Index $(\%)=($ Grains yield $/$ biological yield $) \times 100$

\subsection{Statistical analysis}

The data were statistically analyzed using analysis of variance techniques appropriate for randomized complete block design. Means were compared using LSD test at 0.05 level of probability when the Fvalues were found significant (Jan et al., 2009).

\section{Results And Discussion}

\subsection{Phenology and Physiology}

Data recorded on the number of branches of plant ${ }^{-1}$ are presented in figure 2-A. In comparison, $\mathrm{P}$ and Interaction between $\mathrm{P}$ and $\mathrm{Zn}$ levels was found non-significant. The mean value of the data indicated that a higher number of branches plant ${ }^{-1}(1.88)$ was recorded when $\mathrm{P}$ was applied the rate of $75 \mathrm{~kg} \mathrm{ha}^{-1}$ followed by $50 \mathrm{~kg} \mathrm{Pha}^{-1}$ (1.83) where $25 \mathrm{~kg} \mathrm{P}^{-1}$ results number of branches plant ${ }^{-1}$ (1.17). The higher 
number of branches plant ${ }^{-1}$ (1.93) was recorded when $\mathrm{Zn}$ was applied at the rate of $10 \mathrm{~kg} \mathrm{ha}^{-1}$ followed by $15 \mathrm{~kg} \mathrm{ha}^{-1}(1.92)$, where $0 \mathrm{~kg} \mathrm{Zn} \mathrm{ha}^{-1}$ resulted in the lower number of branches plant ${ }^{-1}$ (1.58).

Data recorded on the number of plants $\mathrm{m}^{-2}$, are presented in figure 2-B. Statistical analysis of the data showed that $\mathrm{Zn}$ had a significant influence on the number of plants $\mathrm{m}^{-2}$ while $\mathrm{P}$ and interaction between $\mathrm{P}$ and $\mathrm{Zn}$ levels were found non-significant. The mean value of the data indicated that a higher number of plants $\mathrm{m}^{-2}$ (22.9) was recorded when $P$ was applied at the rate of $75 \mathrm{~kg} \mathrm{ha}^{-1}$, followed by a control plot (21.6), whereas $25 \mathrm{~kg} \mathrm{Pha}^{-1}$ had the least number of plant $\mathrm{m}^{-2}$ (20.3). The higher number of plants $\mathrm{m}^{-2}$ (24) was recorded when $\mathrm{Zn}$ was applied at the rate of $15 \mathrm{~kg} \mathrm{ha}^{-1}$ followed by $10 \mathrm{~kg} \mathrm{ha}^{-1}(23)$, where the least number of plant $\mathrm{m}^{-2}(17)$ were noted in the plot where no $\mathrm{Zn}$ was applied.

Data recorded on the number of leaves plant ${ }^{-1}$ are shown in figure 2-C. Statistical analysis of the data shows that $P$ and $Z n$ significantly influence the number of leaves plant ${ }^{-1}$. While Interaction between $P$ and $\mathrm{Zn}$ levels was found non-significant. The mean value of the data indicated that a higher number of leaves plant $^{-1}$ (8.8) was observed when $\mathrm{P}$ was applied at the rate of $75 \mathrm{~kg} \mathrm{ha}^{-1}$ followed by $0 \mathrm{~kg}^{-1}$ phosphorous ha${ }^{1}$ (8.7), where $50 \mathrm{~kg} \mathrm{Pha}^{-1}$ resulted in the lower number of leaves plant ${ }^{-1}$ (8). The higher number of leaves plant $^{-1}$ (9) was recorded when $\mathrm{Zn}$ was applied at the rate of $10 \mathrm{~kg} \mathrm{ha}^{-1}$ followed by $15 \mathrm{~kg} \mathrm{ha}^{-1}(8.8)$, where $0 \mathrm{~kg} \mathrm{Zn} \mathrm{ha}{ }^{-1}$ resulted in (7.7) lower number of leaves plant ${ }^{-1}$.

Data associated with plant height are presented in figure 2-D. Statistical analysis of the data shows that Zn significantly affects plant height while $\mathrm{P}$ and Interaction between $\mathrm{P}$ and $\mathrm{Zn}$ levels were found nonsignificant. Mean data shows that higher plant height (95.1) was observed when $\mathrm{P}$ was applied at the rate of $75 \mathrm{~kg} \mathrm{ha}^{-1}$ followed by $50 \mathrm{~kg} \mathrm{P} \mathrm{ha}^{-1}$ (93.6), where $0 \mathrm{~kg} \mathrm{P}^{-1}$ results from low plant height (88.6). Higher plant height (95.8) was recorded when Zn was applied at the $5 \mathrm{~kg} \mathrm{ha}^{-1}$ followed by $10 \mathrm{~kg} \mathrm{ha}$ ${ }^{1}$ (95.1). Where $0 \mathrm{~kg} \mathrm{Zn} \mathrm{ha}{ }^{-1}$ resulted in lower plant height (81.9).

\subsection{Grain yield and yield traits $\left(\mathrm{kg} \mathrm{ha}^{-1}\right)$}

Results showed that $P$ and $Z n$ levels significantly affected the number of pods (figure $3 A$ ). While Interaction between $\mathrm{P}$ and $\mathrm{Zn}$ levels was found non-significant (Figure 3). The mean value of the data indicated that higher numbers of pods (10.3) were observed when $\mathrm{P}$ was applied at the rate of $25 \mathrm{~kg} \mathrm{ha}^{-1}$ followed by $75 \mathrm{~kg} \mathrm{Pha}^{-1}$ (10), where the control plot resulted in the lower number of pods (9.2). For $\mathrm{Zn}$, higher numbers of pods (10.2) were observed when Zn was applied at the $5 \mathrm{~kg} \mathrm{ha}^{-1}$ followed by $10 \mathrm{~kg} \mathrm{Zn}$ $\mathrm{ha}^{-1}(10.1)$. Control plots resulted in lower numbers of pods (9). Similarly the grains $\mathrm{pod}^{-1}$ were also affected by $\mathrm{Zn}$ and $\mathrm{P}$ application (Figure 3B). In comparison, $\mathrm{P}$ and interaction between $\mathrm{P}$ and $\mathrm{Zn}$ levels were found non-significant. Mean data shows that a maximum number of grains pod $^{-1}$ (10.1) was observed when $P$ was applied at the rate of $50 \mathrm{~kg} \mathrm{ha}^{-1}$ followed by $25 \mathrm{~kg} \mathrm{P}^{-1}$ ha). Whereas $\mathrm{P}$

application at the rate of $50 \mathrm{~kg} \mathrm{ha}^{-1}$ resulted in a lower number of grains (9.6). The higher number of grain 
$\operatorname{pod}^{-1}$ (10.3) was recorded when Zn was applied at the rate of $5 \mathrm{~kg} \mathrm{ha}^{-1}$ followed by $10 \mathrm{~kg} \mathrm{ha}^{-1}(10)$, whereas the control plot resulted in the lower number of grains (8.7).

Maximum numbers of nodules (13.1) were observed with the application of $50 \mathrm{~kg} \mathrm{P} \mathrm{ha}^{-1}$ followed by 75 $\mathrm{kg} \mathrm{P} \mathrm{ha-1} \mathrm{(12.3),} \mathrm{while} \mathrm{the} \mathrm{lowest} \mathrm{(10.6)} \mathrm{nodules} \mathrm{were} \mathrm{observed} \mathrm{in} \mathrm{the} \mathrm{control} \mathrm{plot} \mathrm{(Figure} \mathrm{3C).} \mathrm{Similarly,}$ higher numbers of nodules (12.7) were observed with the application of $15 \mathrm{~kg} \mathrm{Zn} \mathrm{ha}^{-1}$ and followed by the control plot (11.7), while the lowest (11.1) nodules were observed on $10 \mathrm{~kg} \mathrm{Zn} \mathrm{ha}^{-1}$. Results on grain yield showed that that a higher grain yield $\left(826.7 \mathrm{~kg} \mathrm{ha}^{-1}\right)$ was observed when $\mathrm{P}$ was applied at the rate of $25 \mathrm{~kg} \mathrm{ha}^{-1}$, followed by $50 \mathrm{~kg} \mathrm{P} \mathrm{ha}^{-1}\left(792.5 \mathrm{~kg} \mathrm{ha}^{-1}\right)$, where a lower grain yield $\left(737.4 \mathrm{~kg} \mathrm{ha}^{-1}\right)$ were obtained from the control plot. Higher grain yield $\left(835.0 \mathrm{~kg} \mathrm{ha}^{-1}\right)$ was recorded when $\mathrm{Zn}$ was applied at the rate of $5 \mathrm{~kg} \mathrm{ha}^{-1}$ followed by $15 \mathrm{~kg} \mathrm{ha}^{-1}\left(800 \mathrm{~kg} \mathrm{ha}^{-1}\right)$. Whereas lower grain yield $\left(719.9 \mathrm{~kg} \mathrm{ha}^{-1}\right)$ was recorded at plot had $10 \mathrm{~kg} \mathrm{Zn} \mathrm{ha}^{-1}$.

Maximum (4493.4 $\mathrm{kg} \mathrm{ha}^{-1}$ ) biological yield was observed with the application of $25 \mathrm{~kg} \mathrm{P} \mathrm{ha}^{-1}$, while the lowest (3543.1 $\mathrm{kg} \mathrm{ha}^{-1}$ ) biological yield was observed for $75 \mathrm{~kg} \mathrm{P} \mathrm{ha}^{-1}$ (Table 1). Similarly, Zn has a maximum biological yield $\left(4511.1 \mathrm{~kg} \mathrm{ha}^{-1}\right)$ with the application of $15 \mathrm{~kg} \mathrm{ha}^{-1}$, while the lowest $(3630.3 \mathrm{~kg}$ $\mathrm{ha}^{-1}$ ) was recorded in the control plot. Higher (39.4) thousand-grains weight was observed with the application of $25 \mathrm{~kg} \mathrm{P} \mathrm{ha}^{-1}$. followed by (38.8g) at the rate of $75 \mathrm{~kg} \mathrm{p} \mathrm{ha}^{-1}$ (Table 2). While the lowest (36.8g) thousand grains weight were observed for the control plot. Similarly, $\mathrm{Zn}$ has a significant influence on thousand grains weight, having a higher thousand grains weight $(42.3 \mathrm{~g})$ for application of $15 \mathrm{~kg} \mathrm{Zn} \mathrm{ha}^{-1}$, while the lowest $(34.4 \mathrm{~g})$ thousand grains weight was recorded in the control plot. $\mathrm{P}$ and $\mathrm{Zn}$ had significant effects, while their interaction was non-significant. The higher harvest index (21.73\%) was observed when $\mathrm{P}$ was applied at the rate of $75 \mathrm{~kg} \mathrm{ha}^{-1}$ followed by $0 \mathrm{~kg} \mathrm{ha}^{-1}(20.54 \%)$, where $25 \mathrm{~kg} \mathrm{ha}^{-1}$ resulted in a lower harvest index (19.30\%) (Table 3).. For Zn higher harvest index (23.0\%) was observed when $\mathrm{Zn}$ was applied at the rate of $5 \mathrm{~kg} \mathrm{ha}^{-1}$, followed by a control plot (21.3\%). Furthermore, the application of $15 \mathrm{~kg} \mathrm{Zn} \mathrm{ha}^{-1}$ resulted in a lower harvest index (18.3\%).

Table $1 \quad$ Effect of $\mathrm{P}$ and $\mathrm{Zn}$ on biological yield of mung bean. 


\begin{tabular}{llllll} 
Zn $\left(\mathrm{kg} \mathrm{ha}^{-1}\right)$ & \multicolumn{5}{l}{$\mathrm{P}\left(\mathrm{kg} \mathrm{ha}^{-1}\right)$} \\
\hline & Control & 25 & 50 & 75 & Mean \\
\hline Control & 3233.1 & 4203.9 & 4301.1 & 2782.9 & $3630.3 \mathrm{~b}$ \\
\hline 5 & 3515.4 & 4456.7 & 4001.7 & 3147.7 & $3780.4 \mathrm{~b}$ \\
\hline 10 & 3885.2 & 4680.1 & 3659.4 & 3476.7 & $3925.3 \mathrm{ab}$ \\
\hline 15 & 4328.1 & 4632.9 & 4318.2 & 4765.0 & $4511.1 \mathrm{a}$ \\
\hline Mean & $3740.5 \mathrm{~b}$ & $4493.4 \mathrm{a}$ & $4070.1 \mathrm{ab}$ & $3543.1 \mathrm{~b}$ & \\
\hline
\end{tabular}

Table 2. Effect of $P$ and $\mathrm{Zn}$ on thousand-grain weight (gram) of mungbean.

\begin{tabular}{llllll} 
Zn $\left(\mathrm{kg} \mathrm{ha}^{-1}\right)$ & \multicolumn{5}{c}{$\mathrm{P}\left(\mathrm{kg} \mathrm{ha}^{-1}\right)$} \\
\hline & Control & 25 & 50 & 75 & Mean \\
\hline Control & 29.7 & 38.0 & 34.2 & 35.7 & $34.4 \mathrm{~d}$ \\
\hline 5 & 37.3 & 38.0 & 37.3 & 37.1 & $37.4 \mathrm{c}$ \\
\hline 10 & 38.7 & 39.3 & 40.0 & 39.0 & $39.3 \mathrm{~b}$ \\
\hline 15 & 41.3 & 42.3 & 42.2 & 43.4 & $42.3 \mathrm{a}$ \\
\hline Mean & $36.8 \mathrm{~b}$ & $39.4 \mathrm{a}$ & $38.4 \mathrm{a}$ & $38.8 \mathrm{a}$ &
\end{tabular}

Table 3. Effect of $P$ and $Z n$ on harvest index of mung bean.

\begin{tabular}{llccll} 
Zn $\left(\mathrm{kg} \mathrm{ha}^{-1}\right)$ & \multicolumn{5}{c}{$\mathrm{P}\left(\mathrm{kg} \mathrm{ha}^{-1}\right)$} \\
\hline & control & 25 & 50 & 75 & Mean \\
\hline Control & 21.2 & 23.3 & 20.2 & 20.5 & $21.3 \mathrm{ab}$ \\
\hline 5 & 25.1 & 16.0 & 22.7 & 28.5 & $23.0 \mathrm{a}$ \\
\hline 10 & 17.9 & 18.4 & 18.1 & 20.8 & $18.8 \mathrm{~b}$ \\
\hline 15 & 18.0 & 19.6 & 18.5 & 17.2 & $18.3 \mathrm{~b}$ \\
\hline Mean & $20.54 \mathrm{a}$ & $19.30 \mathrm{a}$ & $19.89 \mathrm{a}$ & $21.73 \mathrm{a}$ &
\end{tabular}

Mean followed by different letters are found significant at $5 \%$ level of probabilities. 


\section{Discussion}

Micronutrient insufficiency is the primary cause of low crop development and production in arable soils (Imtiaz et al., 2011). Due to intensive agricultural practices, unwise use of mineral nutrition, breeding of high yielding and advanced varieties, and removal of huge quantities of nutrients at every crop harvest with lower nutrients returns to soils, the degree and extent of nutrient deficiency in arable soils has recently had serious consequences, resulting in lower micronutrients including zinc ( $Z n$ ) in soil (Kanwal et al., 2019). Therefore to we conducted a field experiment on different $Z n$ rates in combination with $P$ rates to determine its effect on mungbean growth, yield and yield components. Our results showed that $\mathrm{P}$ and Zn significantly effected number of plants $\mathrm{m}^{-2}$, number of branches plant ${ }^{-1}$, number of leaves plant 1 and plant height $(\mathrm{cm})$ pods plant ${ }^{-1}$, grains pod ${ }^{-1}$, nodules plant ${ }^{-1}$ and grain yield $\left(\mathrm{kg} \mathrm{ha}^{-1}\right)$, biological yield, thousand grains weight, and harvest index. The plots treated with $15 \mathrm{~kg} \mathrm{ha}^{-1} \mathrm{Zn}$ in combination with $50 \mathrm{~kg} \mathrm{P}^{-1}$ Resulted in higher number of plants $\mathrm{m}^{-2}$, more branches plant ${ }^{-1}$, maximum leaves plant

${ }^{1}$ and maximum plant height $(\mathrm{cm})$, higher number of pods plant ${ }^{-1}$, more grains pod ${ }^{-1}$, extra nodules plant ${ }^{-1}$ and higher grain yield $\left(\mathrm{kg} \mathrm{ha}^{-1}\right)$. The possible explanation for these increments might due to the $\mathrm{Zn}$ promotes nodulation and nitrogen fixation in leguminous crops (Masood, et al., 2022; Shahrajabian et al., 2022; Gough et al., 2021). Furthermore Zn is important in the formation of auxin, which increases cell volume and increases plant height (Wang et al., 2016; Oguchi et al., 2004). Cakmak et al. (2000) reported that $\mathrm{Zn}$ is essential for active enzymatic activity, root cell elongation, and reducing free radical damage to the cell. Another possible explanation for these results that when $\mathrm{Zn}$ and $\mathrm{P}$ applied to soil improved soil physical and chemical properties which consequently improved mungbean growth, yield and yield component (Singh, et al., 2013). A previous study documented that compared to control, $\mathrm{Zn}$ increased branches numbers in plants and leaf area of mungbean (Haider et al., 2021). Nair studied the genetic diversity of mungbean for iron and zinc and discovered a large potential for improvement through biofortification, finding 20-40 g Zn concentration $\mathrm{kg}^{-1}$ for dry mungbean seed, which was virtually identical in our work. Overall the results showed that the addition of $\mathrm{Zn}$ and $\mathrm{P}$ fertilizer to soil can improve growth, yield and yield component of mungbean.

\section{Conclusion}

Our results showed that the growth, yield and yield components of mungbean were improved in $\mathrm{Zn}$ and $\mathrm{P}$ fertilizer application. On the basis of our results it is concluded that $P$ application at the rate of $25 \mathrm{~kg} \mathrm{ha}^{-1}$ produced a higher grain yield as compared to 75 and $50 \mathrm{~kg} \mathrm{ha}^{-1}$. Whereas, Zn application at the rate of 5 $\mathrm{kg} \mathrm{ha}^{-1}$ produced a higher grain yield than 10 and $15 \mathrm{~kg}$ ha- 1 hence lower rate of $5 \mathrm{~kg}$ ha-1 is recommended for higher yield of mungbean in agro-ecological condition Mardan.

\section{Declarations}

Conflict of Interest 


\section{Funding Information}

No funding

\section{References}

1. Ahmad, R.I.A.Z., Ikraam, M., Ullah, E.H.S.A.N. and Mahmood, A.S.I.F., 2003. Influence of different fertilizer levels on the growth and productivity of three mungbean (Vigna radiata) cultivars. International Journal of Agriculture \& Biology, 5(3), pp.335-338.

2. Ahsin, M., Hussain, S., Rengel, Z. and Amir, M., 2020. Zinc status and its requirement by rural adults consuming wheat from control or zinc-treated fields. Environmental geochemistry and health, 42(7), pp.1877-1892.

3. Aimen, A., Basit, A., Bashir, S., Aslam, Z., Shahid, M.F., Amjad, S., Mehmood, K., Aljuaid, B.S., ElShehawi, A.M., Zuan, A.T.K. and Farooq, S. Sustainable phosphorous management in two different soil series of Pakistan by evaluating dynamics of phosphatic fertilizer source. Saudi Journal of Biological Sciences.(2021).

4. Amanullah, Alwahibi, M.S., Elshikh, M.S., Alkahtani, J., Muhammad, A., Khalid, S., Ahmad, M., Khan, N., Ullah, S. and Ali, I., 2020. Phosphorus and Zinc Fertilization Improve Zinc Biofortification in Grains and Straw of Coarse vs. Fine Rice Genotypes. Agronomy, 10(8), p.1155.

5. Amanullah, Yar, M., Khalid, S., Elshikh, M.S., Akram, H.M., Imran, Al-Tawaha, A.R.M., Ahmad, M., Muhammad, A., Ullah, S. and Ali, I., 2022. Phenology, growth, productivity, and profitability of mungbean as affected by potassium and organic matter under water stress vs. no water stress conditions. Journal of Plant Nutrition, 45(5), pp.629-650.

6. Arunachalam, P., Kannan, P., Prabukumar, G. and Govindaraj, M. Zn deficiency in Indian soils with special focus to enrich Zn in peanut. African Journal of Agricultural Research, (2013). 8(50), pp.6681-6688.

7. Bashir, K., Ali, S. and Umair, A., 2011. Effect of different phosphorus levels on xylem sap components and their correlation with growth variables of mash bean. Sarhad Journal of Agriculture, 27(4), pp.595-601.

8. Bindraban, P.S., Dimkpa, C.O. and Pandey, R., 2020. Exploring P fertilizers and fertilization strategies for improved human and environmental health. Biology and Fertility of Soils, 56(3), pp.299-317.

9. Brady, N.C. and R.R. Weil. 2004. The Nature and Properties of Soils. 13th Ed.. Pearson

10. Cakmak, l., 2000. Tansley Review No. 111: possible roles of zinc in protecting plant cells from damage by reactive oxygen species. New phytologist, 146(2), pp.185-205.

11. Detzel, A., Krüger, M., Busch, M., Blanco-Gutiérrez, I., Varela, C., Manners, R., Bez, J. and Zannini, E., 2021. Life cycle assessment of animal-based foods and plant-based protein-rich alternatives: an 
environmental perspective. Journal of the Science of Food and Agriculture.

12. Gobarah, M.E., Mohamed, M.H. and Tawfik, M.M., 2006. Effect of $P$ fertilizer and foliar spraying with Zn on growth, yield and quality of groundnut under reclaimed sandy soils. J App Sci Res, 2(8), pp.491-496.

13. Gough, E.C., Owen, K.J., Zwart, R.S. and Thompson, J.P., 2021. Arbuscular mycorrhizal fungi acted synergistically with Bradyrhizobium sp. to improve nodulation, nitrogen fixation, plant growth and seed yield of mung bean (Vigna radiata) but increased the population density of the root-lesion nematode Pratylenchus thornei. Plant and Soil, pp.1-22.

14. Haider, M.U., Hussain, M., Farooq, M. and Nawaz, A., 2020. Optimizing Zn seed priming for improving the growth, yield and grain biofortification of mungbean (Vigna radiata (L.) wilczek). Journal of Plant Nutrition, 43(10), pp.1438-1446.

15. Haider, M.U., Hussain, M., Farooq, M., Ul-Allah, S., Ansari, M.J., Alwahibi, M.S. and Farooq, S., 2021. Zinc biofortification potential of diverse mungbean [Vigna radiata (L.) Wilczek] genotypes under field conditions. PLOS ONE, 16(6), p.e0253085.

16. Hakim, S., Imran, A. and Mirza, M.S., 2021. Phylogenetic diversity analysis reveals Bradyrhizobium yuanmingense and Ensifer aridi as major symbionts of mung bean (Vigna radiata L.) in Pakistan. Brazilian Journal of Microbiology, 52(1), pp.311-324.

17. Imtiaz, M., Rashid, A., Khan, P., Memon, M.Y. and Aslam, M., 2010. The role of micronutrients in crop production and human health. Pak. J. Bot, 42(4), pp.2565-2578.

18. Iqbal, A., Xie, H., He, L., Ahmad, S., Hussain, I., Raza, H., Khan, A., Wei, S., Quan, Z., Wu, K. and Ali, I., 2021. Partial substitution of organic nitrogen with synthetic nitrogen enhances rice yield, grain starch metabolism and related genes expression under the dual cropping system. Saudi Journal of Biological Sciences, 28(2), pp.1283-1296.

19. Masood, F., Ahmad, S. and Malik, A., 2022. Role of Rhizobacterial Bacilli in Zinc Solubilization. In Microbial Biofertilizers and Micronutrient Availability (pp. 361-377). Springer, Cham.

20. Nair, R.M., Yang, R.Y., Easdown, W.J., Thavarajah, D., Thavarajah, P., Hughes, J.D.A. and Keatinge, J.D.H., 2013. Biofortification of mungbean (Vigna radiata) as a whole food to enhance human health. Journal of the Science of Food and Agriculture, 93(8), pp.1805-1813.

21. Oguchi, K., Tanaka, N., Komatsu, S. and Akao, S., 2004. Methylmalonate-semialdehyde dehydrogenase is induced in auxin-stimulated and zinc-stimulated root formation in rice. Plant cell reports, 22(11), pp.848-858.

22. Rahman M.M., Bhuiyan M. M. H., Sutradhar G.N.C., Rahman M. M. and Paul A.K. 2008. Replication Proteins. Ann. Rev., Biochem. 61, 897-946.

23. Read, S.A., Obeid, S., Ahlenstiel, C. and Ahlenstiel, G., 2019. The role of $Z n$ in antiviral immunity. Advances in nutrition, 10(4), pp.696-710.

24. Rehman, A., Farooq, M., Ozturk, L., Asif, M. and Siddique, K.H., 2018. Zn nutrition in wheat-based cropping systems. Plant and Soil, 422(1), pp.283-315. 
25. Sadiq, G., Khan, A.A., Inamullah, A.R., Fayyaz, H., Naz, G., Nawaz, H., Ali, I., Raza, H., Amin, J., Ali, S. and Khan, H.A., 2017. Impact of $P$ and potassium levels on yield and yield components of maize. Pure and Applied Biology (PAB), 6(3), pp.1071-1078.

26. Shahrajabian, M.H., Sun, W. and Cheng, Q., 2022. A survey of biological nitrogen fixation in adzuki beans, soybeans, and mung beans, three legumes in traditional Chinese medicine. In Functional Foods and Nutraceuticals in Metabolic and Non-Communicable Diseases (pp. 301-316). Academic Press.

27. Shakya, A., Kumar, P., Verma, A.P., Raj, A. and Batham, P., 2019. Studies on population dynamics of sucking insect pests whitefly (Bemisia tabaci), jassid (Empoasca kerri) and thrips (Caliothrips indicus) on mungbean [Vigna radiata (L.) Wilczek].

28. Singh, A.K., Meena, M.K., Bharati, R.C. and Gade, R.M., 2013. Effect of sulphur and zinc management on yield, nutrient uptake, changes in soil fertility and economics in rice (Oryza sativa)-lentil (Lens culinaris) cropping system. Indian J. Agril. Sci, 83(3), pp.344-348.

29. Singh, K., Gera, R., Sharma, R., Maithani, D., Chandra, D., Bhat, M.A., Kumar, R. and Bhatt, P., 2021. Mechanism and application of Sesbania root-nodulating bacteria: an alternative for chemical fertilizers and sustainable development. Archives of Microbiology, pp.1-12.

30. Sulieman, S. and Tran, L.S.P., 2015. Phosphorus homeostasis in legume nodules as an adaptive strategy to phosphorus deficiency. Plant Science, 239, pp.36-43.

31. Tarafder, S., Rahman, M.A., Hossain, M.A. and Chowdhury, M.A.H., 2020. Yield of Vigna radiata L. And post-harvest soil fertility in response to integrated nutrient management. Agricultural and Biological Sciences Journal, 6(1), pp.32-43.

32. Teferie, B.B., Admasu, M.A. and Damessa, G.G., 2020. Assessment and characterization of mung bean (Vigna radiata) bacterial brown spot in Eastern Amhara, Ethiopia. African Journal of Agricultural Research, 16(5), pp.606-621.

33. Thapa, S., Bhandari, A., Ghimire, R., Xue, Q., Kidwaro, F., Ghatrehsamani, S., Maharjan, B. and Goodwin, M. Managing Micronutrients for Improving Soil Fertility, Health, and Soybean Yield. Sustainability, (2021). 13(21), p.11766.

34. Ullah, S., Liang, H., Ali, I., Zhao, Q., Iqbal, A., Wei, S., Shah, T., Yan, B. and Jiang, L., 2020. Biochar coupled with contrasting nitrogen sources mediated changes in carbon and nitrogen pools, microbial and enzymatic activity in paddy soil. Journal of Saudi Chemical Society, 24(11), pp.835-849.

35. Umair Hassan, M., Aamer, M., Umer Chattha, M., Haiying, T., Shahzad, B., Barbanti, L., Nawaz, M., Rasheed, A., Afzal, A., Liu, Y. and Guoqin, H., 2020. The critical role of Zn in plants facing the drought stress. Agriculture, 10(9), p.396.

36. Wang, S., Ren, X., Huang, B., Wang, G., Zhou, P. and An, Y., 2016. Aluminium-induced reduction of plant growth in alfalfa (Medicago sativa) is mediated by interrupting auxin transport and accumulation in roots. Scientific reports, 6(1), pp.1-13.

\section{Figures}




\section{Figure 1}

Map representing an experimental location in Mardan city, KPK Province, Pakistan, using Google maps.

\section{Figure 2}

Effect of $\mathrm{P}$ and $\mathrm{Zn}$ on the number of plants $\mathrm{m}^{-2}$, number of branches plant ${ }^{-1}$, number of leaves plant ${ }^{-1}$ and plant height $(\mathrm{cm})$ of mungbean.

\section{Figure 3}

Effect of $\mathrm{P}$ and $\mathrm{Zn}$ application on pods plant ${ }^{-1}$, grains pod $^{-1}$, nodules plant ${ }^{-1}$ and grain yield $\left(\mathrm{kg} \mathrm{ha}^{-1}\right)$ of mungbean. 